Писаренко В. В., доктор економічних наук,

Писаренко П. В., доктор сільськогосподарських наук,

Писаренко В. М., доктор сільськогосподарських наук,

Лук’яненко Г. В. *, Панченко С. І. **, Писаренко Ю. Г. ***, аспіранти

Полтавська державна аграрна академія

\title{
ЕКОЛОГО-ЕКОНОМІЧНА ЕФЕКТИВНІСТЬ ВИКОРИСТАННЯ СИДЕРАТІВ
}

\section{Рецензент - доктор економічних наук, професор Х. 3. Махмудов}

\begin{abstract}
Викладені результати досліджень економічної ефективності використання сидеральних культур. Встановлено, що вартість біомаси еспариету виколистого, вики озимої, гречки, буркуна білого досягає від 500 до 3000 грн на гектар. Вартість поживних речовин (NPK), накопичених у біомасі, становить від 1000 до 2500 тис. грн на гектар. Розрахований загальний економічний ефект використання сидеральних культур в умовах Полтавської області, який становить від 1500 до 6000 тис. грн на гектар.
\end{abstract}

Ключові слова: ефективність, сидеральні культури, родючість трунту, розрахунковоеквівалентний метод, витрати

Постановка проблеми. Цінність і важливість сидеральних культур, не обмежується лише властивістю чудового замінника традиційних органічних добрив. У сучасних умовах поглиблення спеціалізації приватних господарств і концентрації сільськогосподарського виробництва відбувається скорочення періоду тривалості ротації сівозмін, суттєве насичення їх одновидовими або близькими за біологічними особливостями культурами, що призводить до певного напруження фітосанітарного стану в агроценозах.

Тому особливого значення у контексті сівозмінного фактора і для підтримання родючості грунту набувають сидеральні культури.

Аналіз основних досліджень i публікацій, у яких започатковано розв'язання проблеми. Термін «сидерація» вперше запропонував у XIX сторіччі французький вчений Ж. Виль [6]. Заробку спеціальних посівів рослин, надземна маса яких частково або повністю заробляється у грунт, називають «сидерацією», а саму культуру - сидератом.

Ми вважаємо, що під сидерацією потрібно розуміти заробку не лише надземної маси, а й кореневої системи, тобто усієї рослинної маси.
Рослинну масу на зелене добриво широко використовують майже в усіх країнах Європи. Аналіз літератури $[4-6,9,14]$ свідчить, що для сидерації використовують понад 60 різних культур. Сидеральні культури використовують для збагачення грунту поживними речовинами, покращання структури його верхнього шару, водного, повітряного, теплового, фітосанітарного режиму та захисту грунту від ерозії.

Зелене добриво $є$ невичерпним, постійно поновлювальним джерелом органічної речовини. За даними наукових досліджень $[5,6,9,14]$, сидерати за своєю ефективністю прирівнюються до напівперепрілого гною 3 коефіціснтом 1,5. Необхідно зауважити, що витрати енергії на удобрення одного гектара 3 розрахунку $30 \mathrm{~T}$ гною збільшують витрати на вирощування сидеральної культури більше ніж у 2,5 разу $[6,9,14]$.

Вибираючи ту чи іншу сидеральну культуру, потрібно враховувати кліматичні, грунтові й організаційно-економічні умови господарства. Особливу увагу слід звертати на насінництво, поскільки вартість насіння становить основну статтю витрат за вирощування культур на зелене добриво.

Відразу після сходів сидерати починають «працювати» на родючість грунту. Сонце на полях, зайнятих ними, не пересушує верхній шар, не вбиває мікрофлору, а лише сприяє фотосинтезу. Бобові культури збагачують грунт азотом, який фіксують із повітря бульбочкові бактерії, розміщені на їхніх коренях. Накопиченого азоту вистачає як самій сидеральній культурі, так і наступній після неї культурі у сівозміні. Позитивний вплив сидерації на родючість грунту й урожайність сільськогосподарських культур зберігається протягом трьох років. Так само, як і гній, сидерати є важливим джерелом для синтезу органічної речовини грунту.

\footnotetext{
* Керівник-доктор економічних наук В. В. Писаренко

** Керівник-доктор сільськогосподарських наук, професор В. М. Писаренко

*** Керівник - кандидат економічних наук О. В. Дорофєєв
} 
В якості сидератів здебільшого висівають бобові культури (еспарцет виколистий, люцерна посівна, вика яра, буркун, люпин, серадела), які більше корисні для збагачення грунту поживними речовинами. Широко використовують редьку олійну, гірчицю, гречку, фацелію та інші. Висівають також суміші, зокрема: вику яру та овес посівний, редьку олійну та овес посівний тощо.

Під впливом бобових сидератів у 4-7 разів збільшується кількість бульбочкових бактерій, значно підвищується ферментативна активність грунту, покращуються його фітосанітарні та водно-фізичні властивості, створюються умови для інтенсивного розвитку мікроорганізмів і мікрофауни, яка визначає родючість даного поля. Позитивна дія сидерату триває протягом 3-4 років.

Широке впровадження сидератів сприяє включенню в малий кругообіг із більш глибоких генетичних горизонтів грунту невикористаних резервів фосфору, калію, кальцію, магнію та інших елементів живлення рослин.

Сидеральні культури вирощують із підсівом до покривної культури, поукісно і пожнивно. У першому випадку, у рік вирощування, сидерати підсівають під покривну культуру (ячмінь ярий, кукурудза на зелений корм та ін.) або висівають безпосередньо після збирання основної культури (поукісно, пожнивно). В процесі вирощування сидеральних культур із підсівом під покривну культуру поле обробляють за технологією підготовки грунту для покривної культури. 3 метою вирощування сидератів післяукісно або пожнивно грунт готують рекомендованими агрегатами на глибину 6-8 сантиметрів. Головне не допустити розриву між збиранням попередника і сівбою сидерата, бо це призводить до значної втрати вологи i, як наслідок, гіршого розвитку сидеральної культури. Важливо також забезпечити загортання насіння у вологий грунт. Сівбу проводять відразу ж за обробітком грунту або одночасно 3 ним. Основний спосіб сівби звичайний рядковий; норми висіву для післяукісного або пожнивного посіву збільшують на $20-25 \%$ порівняно 3 оптимальними умовами (за сівби весною) і загортають його на 1-2 см глибше. Після сівби проводять коткування, досходове і післясходове боронування легкими посівними боронами, а на широкорядних посівах і міжрядний обробіток.

Найкращі результати для одержання дружніх сходів і наступного росту сидератів дає саме поверхневий обробіток грунту: зберігається волога, до мінімуму зводиться негативна дія на нього ерозії, зменшується забур'яненість і кількість проходів агрегатів, не ущільнюється грунт. У поєднанні з сидератами поверхневий обробіток забезпечує найефективніше збереження та підвищення родючості грунту.

За вирощування сидеральних культур поліпшується родючість грунтів, що створюють самі рослини. Цю властивість вирахувано навіть математично. За своє життя на формування біомаси рослина бере з грунту лише 10 відсотків «матеріалу», а 90 відсотків одержує 3 повітря, енергії сонячних променів.

Таким чином, на кожну тонну врожаю сухої речовини (основної та побічної продукції) багаторічні бобові трави (люцерна, еспарцет, конюшина) фіксують із повітря приблизно 30-38, люпин і кормові боби - 20-27, горох - 10-15 кг азоту. Поверхневий обробіток і залишки на поверхні рослинних решток значно підвищують азотфіксацію бобовими культурами.

Практично недослідженим залишається питання економічної ефективності вирощування сидеральних культур. Відповідно, актуальним $€$ узагальнення літературних даних та проведення власних досліджень, які підтверджують доцільність використання сидератів 3 економічної точки зору. При цьому використовувався розрахунково-еквівалентний метод, який передбачає врахування кількості біомаси сидерату з одного гектара, його вартості у перерахунку на гній (коефіцієнт 1,5 у відношенні до напівперепрілого гною), витрати на вирощування та вартість біомаси сидерату. Вартість гною розраховувалася на основі реальних витрат у ПП «Агроекологія» Шишацького району Полтавської області. Зокрема вартість гною після транспортування його 3 ферми у польові бурти станом на червень 2012 року становила 21,5 грн за 1 тонну. Внесення гною коштувало 17,14 грн за 1 тонну. Відповідно, загальні витрати становлять 38,9 грн за 1 тонну (табл. 1).

I3 даних таблиці 1 видно, що найбільшу кількість біомаси забезпечують посіви гречки, яка дискується двічі. Суть цієї технології, запатентованої в ПП «Агроекологія», полягає в тому, що перше дискування проводять у фазі утворення перших зрілих плодів. Зароблене зріле зерно знову проростає і у фазі «цвітіння - утворення перших зрілих плодів у рослин» проводиться повторне дискування. За достатнього зволоження формується й третій урожай зеленої маси гречки, який також використовується як сидерат.

Вартість зеленої маси сидерату у перерахунку на вартість гною досягає 3034 грн (у люпину однорічного). Істотною $\epsilon$ вартість біомаси $\mathrm{i}$ 
1. Вартість біомаси сидерату, 2012 p.

\begin{tabular}{|c|c|c|c|c|c|c|c|}
\hline \multirow{2}{*}{ Сидерат } & Кількість & Вартість у & \multicolumn{3}{|l|}{ Витрати на вирощування сидерату, грн/га } & Ефект від \\
& б 1 га (ц) & $\begin{array}{c}\text { перерахунку } \\
\text { на гній (грн) }\end{array}$ & насіння & сівба & $\begin{array}{c}\text { дискуван- } \\
\text { ня }\end{array}$ & разом & $\begin{array}{c}\text { використан- } \\
\text { ня сидерату }\end{array}$ \\
\hline Еспарцет & 275 & 1604,6 & 1000 & 34,65 & 74,25 & 1108,9 & 495,7 \\
\hline Вика озима & 250 & 1458 & 300 & 520 & 74,25 & 628,9 & 829,1 \\
\hline $\begin{array}{c}\text { Вико-вівсяна } \\
\text { суміш }\end{array}$ & 270 & 1575 & 580 & 34,65 & 74,25 & 688,9 & 886,1 \\
\hline Горох кормовий & 350 & 2042 & 750 & 34,65 & 74,25 & 858,9 & 1183,1 \\
\hline Буркун білий & 200 & 1167 & 625 & 34,65 & 74,25 & 733,9 & 433,1 \\
\hline $\begin{array}{c}\text { Люпин } \\
\text { однорічний }\end{array}$ & 520 & 3034 & 720 & 34,65 & 74,25 & 828,9 & 2205,1 \\
\hline $\begin{array}{c}\text { Гречка за } \\
\text { дві заробки }\end{array}$ & 650 & 3792 & 400 & 69,3 & 148,5 & 508,9 & 3293,1 \\
\hline Гірчиця біла & 250 & 1458 & 300 & 34,65 & 74,25 & 408,9 & 1049,1 \\
\hline Суріпиця & 340 & 1984 & 100 & 34,65 & 74,25 & 208,9 & 1775,1 \\
\hline Редька олійна & 450 & 2625 & 160 & 34,65 & 74,25 & 268,9 & 2356,1 \\
\hline Фацелія & 300 & 1750 & 375 & 34,65 & 74,25 & 483,9 & 1266,1 \\
\hline
\end{tabular}

\section{2. Агрохімічна характеристика рослин-сидератів, здійснена розрахунково-еквівалентним} методом

\begin{tabular}{|c|c|c|c|c|c|c|}
\hline \multirow{2}{*}{ Сидерат } & \multirow{2}{*}{$\begin{array}{c}\text { Урожайність } \\
\text { зеленої маси, } \\
\text { ц/га }\end{array}$} & \multicolumn{2}{|c|}{$\begin{array}{c}\text { Накопичено в загальній біомасі } \\
\text { поживних речовин, кг/га }\end{array}$} & \multirow{2}{*}{$\begin{array}{c}\text { Разом, } \\
\text { кг/га }\end{array}$} & $\begin{array}{c}\text { У туках, } \\
\text { кг/га } \\
1 *\end{array}$ \\
\cline { 3 - 5 } & 275 & $\mathrm{~N}$ & $\mathrm{P}_{2} \mathrm{O}_{5}$ & $\mathrm{~K}_{2} \mathrm{O}$ & & \\
\hline Еспарцет & 250 & 25 & 75 & 245 & 510,4 \\
\hline Вика озима & 250 & 160 & 75 & 200 & 435 & 906,3 \\
\hline Вико-вівсяна суміш & 275 & 120 & 35 & 80 & 235 & 489,6 \\
\hline Горох кормовий & 350 & 80 & 70 & 90 & 240 & 500 \\
\hline Буркун білий & 200 & 110 & 45 & 140 & 295 & 614,6 \\
\hline Люпин однорічний & 520 & 230 & 60 & 200 & 490 & 1020,8 \\
\hline Гречка за дві заробки & 650 & 200 & 135 & 305 & 640 & 1333,3 \\
\hline Гірчиця біла & 250 & 60 & 40 & 90 & 190 & 395,8 \\
\hline Суріпиця & 340 & 135 & 55 & 240 & 430 & 895,8 \\
\hline Редька олійна & 450 & 85 & 65 & 245 & 395 & 822,9 \\
\hline Фацелія & 300 & 80 & 50 & 200 & 330 & 687,5 \\
\hline
\end{tabular}

Примітка: 1.* Розрахунок кількості діючої речовини у туках проводиться на основі їхнього вмісту в комплексному мінеральному добриві - нітроамофосці (вартість нітроамофоски на 1.05.2012 p. - 4500 грн за 1 т).

в інших культур. Навіть коли враховується витрати на вирощування сидерату, кошти, які отримані в процесі сидерації, досить вагомі й досягають 3293,1 грн/га (гречка), 2205,1 грн/га (люпин однорічний), 2356,1 грн/га (редька олійна). Підсумовуючи отримані дані, констатуємо: вирощування сидеральних культур забезпечує грунт значною кількістю органічної речовини 3 меншими витратами, ніж використання гною, відповідно, $є$ економічно обгрунтованим.

Разом із тим, вагомим $є$ поповнення грунту основними поживними речовинами, що покращує мінеральне живлення рослин. Отримані дані наведені в таблиці 2.
Матеріали таблиці 2 свідчать, що використання сидеральних культур (як органічних добрив) забезпечують накопичення значної кількості поживних речовин. Так, після двох заробок гречки у грунті накопичується близько 640 кг/га N, $\mathrm{P}_{2} \mathrm{O}_{5}, \mathrm{~K}_{20}$. Значна кількість цих макроелементів залишається після люпину однорічного, вики озимої, суріпиці, редьки олійної, фацелії, еспарцету. Безумовно, найбільша кількість біологічного азоту залишається після таких бобових культур, як люпин однорічний, вика озима, еспарцет, хоча при двох заробітках біомаси гречки цей показник теж вагомий. 
3. Економічна ефективність використання сидеральних культур, 2012 р.

\begin{tabular}{|c|c|c|c|c|c|c|c|}
\hline \multirow{2}{*}{ Сидерат } & \multirow{2}{*}{$\begin{array}{c}\text { Урожай- } \\
\text { ність зеле- } \\
\text { ної маси, } \\
\text { ц/га }\end{array}$} & \multirow{2}{*}{$\begin{array}{c}\text { Вартість у } \\
\text { перера- } \\
\text { хунку на } \\
\text { гній, грн }\end{array}$} & \multicolumn{3}{|c|}{$\begin{array}{c}\text { Вартість діючої речовини } \\
\text { сидерату, грн/кг }\end{array}$} & \multirow{2}{*}{$\begin{array}{c}\text { Загальна вар- } \\
\text { тість діючої } \\
\text { речовини } \\
\text { NPK, грн }\end{array}$} & \multirow{2}{*}{$\begin{array}{c}\text { Загальний } \\
\text { економічний } \\
\text { ефект, } \\
\text { грн/га }\end{array}$} \\
\hline & & & $\mathrm{N}$ & $\mathrm{P}_{2} \mathrm{O}_{5}$ & $\mathrm{~K}_{2} \mathrm{O}$ & & \\
\hline Еспарцет & 250 & 495,7 & 652,5 & 112,5 & 337,5 & 1102,5 & 1598,2 \\
\hline Вика озима & 250 & 829,1 & 720 & 337,5 & 900 & 1957,5 & 2786,6 \\
\hline $\begin{array}{l}\text { Вико-вівсяна } \\
\text { суміш }\end{array}$ & 275 & 886,1 & 540 & 157,5 & 360 & 1057,5 & 1943,6 \\
\hline Горох кормовий & 350 & 1183,1 & 360 & 315 & 405 & 1080 & 2263,1 \\
\hline Буркун білий & 200 & 433,1 & 495 & 202,5 & 630 & 1327,5 & 1760,6 \\
\hline $\begin{array}{c}\text { Люпин одноріч- } \\
\text { ний }\end{array}$ & 520 & 2205,1 & 1035 & 270 & 900 & 2205 & 4410,1 \\
\hline $\begin{array}{c}\text { Гречка за дві } \\
\text { заробки }\end{array}$ & 650 & 3293,1 & 900 & 607,5 & 1372,5 & 2880 & 6173,1 \\
\hline Гірчиця біла & 250 & 1049,1 & 270 & 180 & 405 & 855 & 1904,1 \\
\hline Суріпиця & 340 & 1775,1 & 607,5 & 247,5 & 1080 & 1935 & 3710,1 \\
\hline Редька олійна & 450 & 2356,1 & 382,5 & 292,5 & 1102,5 & 1777,5 & 4133,6 \\
\hline Фацелія & 300 & 1266,1 & 360 & 225 & 900 & 1485 & 2751,1 \\
\hline
\end{tabular}

Зауважимо, що гречці характерна властивість засвоювати важкорозчинні макроелементи, зокрема фосфор, та переводити їх у легкодоступні форми, що використовуються іншими рослинами. За перерахунку діючої речовини основних поживних речовин, наведених у таблиці 2 у фізичну вагу мінеральних добрив (туки), ми отримуємо обсяги добрив, які майже досягають або близькі рекомендованим для основних сільськогосподарських культур. Може виникнути питання: а чи достатньо поживних речовин, вироблених сидератами, для забезпечення оптимального живлення рослин? У зв'язку з цим наводимо науково рекомендовані норми внесення мінеральних добрив для зони лісостепу. Так, для пшениці озимої вони становлять $\mathrm{N}_{90-120} \mathrm{P}_{60} \mathrm{~K}_{90}$, пшениці ярої та сої - $\mathrm{N}_{60} \mathrm{P}_{60} \mathrm{~K}_{60}$, кукурудзи - $\mathrm{N}_{90-120} \mathrm{P}_{60-90} \mathrm{~K}_{90-120}$, соняшнику $-\mathrm{N}_{60} \mathrm{P}_{60-90} \mathrm{~K}_{40-60}$, буряка цукрового (за нестійкого зволоження) $\mathrm{N}_{85-100} \mathrm{P}_{120-130} \mathrm{~K}_{115-125 \text {. }}$

Підсумовуючи викладені матеріли, можна стверджувати, що вирощування сидеральних культур у більшості випадків забезпечує рекомендований режим мінерального живлення основних сільськогосподарських культур.

Екологічна цінність отримання достатньої кількості поживних речовин для культурних рослин не викликає сумніву. Важливим залишається питання економічної ефективності цього заходу. Отримані нами розрахунково-еквівалентним методом дані наведені в таблиці 3.

Із даних таблиці 3 видно, що загальна вартість діючої речовини основних макроелементів, вне- сених сидератом у грунт, за вирощування гречки становить 2880 грн на 1 га, люпину однорічного - 2205 грн, вики озимої - 1957,5 грн, редьки олійної - 1777,5 грн, фацеліi - 1485 грн, еспарцету - 1102,5 гривень.

Висновки. Таким чином, підвищення питомої маси біологічного азоту та інших поживних речовин в агроекосистемах за рахунок збільшення площ сидератів (передусім бобових сидеральних культур) є основним важелем стабілізації продуктивності, енергетичної та економічної ефективності землеробства.

Сидерація є одним із основних чинників органічної системи землеробства. Цей захід обов'язковий і за перехідного (реабілітаційного) землеробства, а також і в умовах інтенсивного землеробства. Використання його збагачує органікою грунт, збільшує кількість поживних речовин, у цілому поліпшує родючість грунту і рентабельність землеробства. За використання сидератів практично зникає необхідність додаткового внесення мінеральних добрив, що $є$ екологічно й економічно обгрунтованим заходом.

Все це забезпечує зростання рентабельності виробництва, сприяє екологічному оздоровленню грунту, поліпшенню його родючості на біологічних принципах ведення господарства, охороні довкілля.

Широке впровадження сидерації сприяє переходу до ресурсозберігаючої, а в майбутньому й органічної системи землеробства. 


\section{БІБЛІОГРАФІЯ}

1. Бентежний талант хлібороба: штрихи до портрета агроеколога Семена Антонця / Укладачі Самородов В. М., Поспєлов С. В.; наук. ред. B. М. Самородов. - Полтава: Дивосвіт, 2010. $236 \mathrm{c}$.

2. Вавилов П. П., Мальшеев Л. Н. Полевые сельскохозяйственные культуры СССР. - М. : Колос, 1984. - $160 \mathrm{c}$.

3. Вирощування гречки та поліпшення стану грунтів / Бондаренко М. П., Єфіменко Д. Я., Страхоліс I. М. [та ін.] : Хімія. Агрономія. Сервис. - № 10 2009. - С. 10-11.

4. Все о сидератах / Н. М. Жирмунская. Центр экологического земледелия. - Днепропетровск, 2006. $-60 \mathrm{c}$.

5. Добривна альтернатива / В. В. Лихочвор. Зерно. - № 3, 2008. - С. 62-72.

6. Довбан К. И. Зеленое удобрение в современном земледелии. - Минск: Белорусская наука, 2009. - 404 c.

7. Какое удобрение лучше? Сидераты! / Под ред. П. Н. Трофименко. Справочник, 2-е изд., доп. K., 2009. $-80 \mathrm{c}$.
8. Органічне землеробство: 3 досвіду ПП «Агроекологія» Шишацького району Полтавської області / Антонець С. С., Антонець А. С., Писаренко В. М. [та ін.] - Полтава : Камелот, 2010. - 198 с.

9. Поспелов С., Самородов В. Сидерация: восстанавливаем почву, улучшаем будущий урожай // Зерно. - 2011. - № 1. - С. 16-22.

10. Розвиток органічного виробництва / Федоров М. М., Ходаківська О. В., Корчинська С. Г.; за ред. М. М. Федорова, О. В. Ходаківської. К. : ННЦ ІАЕ, 2011. - $146 \mathrm{c.}$

11. Рослинництво / О. І. Зінченко, В. Н. Салатенко, М. А. Білоножко. - К. : Аграрна освіта, 2001. $-592 \mathrm{c}$.

12. Рослинництво / С. М. Каленська, О. Я. Шевчук, М. Я.Дмитришак [та ін.] - К. : Вища школа, 2005. - 502 c.

13. Рослинництво / В. В. Лихочвор. - К. : Вища школа, 2004. - 798 с.

14. Сидерати. Їм відроджувати колишню славу українських земель / В. Авраменко // Пропозиція. - № 6, 2003. - С. 36-38. 